\title{
Effect of acute exercise on uncoupling protein 3 is a fat metabolism-mediated effect
}

Citation for published version (APA):

Schrauwen, P., Hesselink, M. K. C., Vaartjes, I., Kornips, C. F. P., Saris, W. H. M., Giacobino, J. P., \& Russell, A. (2002). Effect of acute exercise on uncoupling protein 3 is a fat metabolism-mediated effect. American Journal of Physiology : Endocrinology and Metabolism, 282(1), E11-E17. https://doi.org/10.1152/ajpendo.2002.282.1.E11

Document status and date:

Published: 01/01/2002

DOI:

10.1152/ajpendo.2002.282.1.E11

Document Version:

Publisher's PDF, also known as Version of record

\section{Please check the document version of this publication:}

- A submitted manuscript is the version of the article upon submission and before peer-review. There can be important differences between the submitted version and the official published version of record.

People interested in the research are advised to contact the author for the final version of the publication, or visit the DOI to the publisher's website.

- The final author version and the galley proof are versions of the publication after peer review.

- The final published version features the final layout of the paper including the volume, issue and page numbers.

Link to publication

\footnotetext{
General rights rights.

- You may freely distribute the URL identifying the publication in the public portal. please follow below link for the End User Agreement:

www.umlib.nl/taverne-license

Take down policy

If you believe that this document breaches copyright please contact us at:

repository@maastrichtuniversity.nl

providing details and we will investigate your claim.
}

Copyright and moral rights for the publications made accessible in the public portal are retained by the authors and/or other copyright owners and it is a condition of accessing publications that users recognise and abide by the legal requirements associated with these

- Users may download and print one copy of any publication from the public portal for the purpose of private study or research.

- You may not further distribute the material or use it for any profit-making activity or commercial gain

If the publication is distributed under the terms of Article $25 \mathrm{fa}$ of the Dutch Copyright Act, indicated by the "Taverne" license above, 


\title{
Effect of acute exercise on uncoupling protein 3 is a fat metabolism-mediated effect
}

\author{
PATRICK SCHRAUWEN,${ }^{1}$ MATTHIJS K. C. HESSELINK, ${ }^{2}$ ILONCA VAARTJES, ${ }^{1}$ \\ ESTHER KORNIPS, ${ }^{1,2}$ WIM H. M. SARIS, ${ }^{1}$ JEAN-PAUL GIACOBINO ${ }^{3}$ AND AARON RUSSELL ${ }^{3}$ \\ Department of ${ }^{1}$ Human Biology and ${ }^{2}$ Movement Sciences, Maastricht University, \\ 6200 MD Maastricht, The Netherlands; and ${ }^{3}$ Department of Medical Biochemistry, \\ University of Geneva, 1211 Geneva, Switzerland
}

Received 25 April 2001; accepted in final form 13 August 2001

\begin{abstract}
Schrauwen, Patrick, Matthijs K. C. Hesselink, Ilonca Vaartjes, Esther Kornips, Wim H. M. Saris, Jean-Paul Giacobino, and Aaron Russell. Effect of acute exercise on uncoupling protein 3 is a fat metabolism-mediated effect. Am J Physiol Endocrinol Metab 282: E11-E17, 2002.-Human and rodent uncoupling protein (UCP) 3 mRNA is upregulated after acute exercise. Moreover, exercise increases plasma levels of free fatty acid (FFA), which are also known to upregulate UCP3. We investigated whether the upregulation of UCP3 after exercise is an effect of exercise per se or an effect of FFA levels or substrate oxidation. Seven healthy untrained men [age: $22.7 \pm 0.6 \mathrm{yr}$; body mass index: $23.8 \pm 1.0 \mathrm{~kg} / \mathrm{m}^{2}$; maximal $\mathrm{O}_{2}$ uptake $\left(\dot{\mathrm{V}}_{2}\right.$ max $\left.): 3,852 \pm 211 \mathrm{ml} / \mathrm{min}\right]$ exercised at $50 \% \dot{\mathrm{V}}_{2}$ max for $2 \mathrm{~h}$ and then rested for $4 \mathrm{~h}$. Muscle biopsies and blood samples were taken before and immediately after $2 \mathrm{~h}$ of exercise and 1 and $4 \mathrm{~h}$ in the postexercise period. To modulate plasma FFA levels and fat/glucose oxidation, the experiment was performed two times, one time with glucose ingestion and one time while fasting. UCP3 mRNA and UCP3 protein were determined by RT-competitive PCR and Western blot. In the fasted state, plasma FFA levels significantly increased $(P<0.0001)$ during exercise $(293 \pm 25$ vs. $1,050 \pm 127 \mu \mathrm{mol} / \mathrm{l})$, whereas they were unchanged after glucose ingestion (335 \pm 54 vs. $392 \pm 74$ $\mu \mathrm{mol} / \mathrm{l})$. Also, fat oxidation was higher after fasting $(P<0.05)$, whereas glucose oxidation was higher after glucose ingestion $(P<0.05)$. In the fasted state, UCP3L mRNA expression was increased significantly $(P<0.05) 4 \mathrm{~h}$ after exercise $(4.6 \pm 1.2 \mathrm{vs}$. $9.6 \pm 3.3 \mathrm{amol} / \mu \mathrm{g}$ RNA). This increase in UCP3L mRNA expression was prevented by glucose ingestion. Acute exercise had no effect on UCP3 protein levels. In conclusion, we found that acute exercise had no direct effect on UCP3 mRNA expression. Abolishing the commonly observed increase in plasma FFA levels and/or fatty acid oxidation during and after exercise prevents the upregulation of UCP3 after acute exercise. Therefore, the previously observed increase in UCP3 expression appears to be an effect of prolonged elevation of plasma FFA levels and/or increased fatty acid oxidation.
\end{abstract}

fat oxidation; uncoupling protein; fatty acids; mitochondria

THE HUMAN UNCOUPLING PROTEIN (UCP) 3 uncouples the respiratory chain, producing heat without an increase in ATP production, and is therefore suggested to play a

Address for reprint requests and other correspondence: $\mathrm{P}$ Schrauwen, Nutrition and Toxicology Research Institute Maastricht (NUTRIM), Dept. of Human Biology, Maastricht Univ., P.O. Box 616, 6200 MD Maastricht, The Netherlands (E-mail: p.schrauwen@hb.unimaas.nl). role in human energy metabolism, obesity, and diabetes (30). We have previously shown a positive correlation between metabolic rate and UCP3 mRNA expression in humans (31), although results are conflicting (2). Furthermore, mice overexpressing UCP3 in skeletal muscle are hyperphagic but weigh less than control mice (7). These data indicate that UCP3 could indeed play an important role in thermogenesis; however, several findings regarding the regulation of UCPs do not match with a role for UCP3 in energy metabolism. For example, UCP3 mRNA expression is upregulated during fasting, both in rodents (35) and in humans (19), whereas in a situation of food deprivation conservation of energy is observed (14). An explanation for the unexpected upregulation of UCP3 during fasting comes from the observation that free fatty acids (FFA) upregulate UCP3 mRNA expression both in rodents (35) and in humans (15). During fasting and situations of elevated plasma FFA levels, fat oxidation is also increased, and it has been suggested that UCP3 is involved in the handling of lipids as a fuel (25).

During and after acute endurance exercise, energy expenditure, plasma FFA levels, and substrate oxidation are increased rapidly. The effect of acute endurance exercise on UCP3 mRNA expression has been studied in rodents, showing a rapid upregulation of UCP3 mRNA postexercise $(9,32,36)$. In humans, few data are available regarding the effect of acute exercise on UCP3 mRNA expression. We previously measured UCP3 mRNA expression before and immediately after 80 min of exhaustive cycling exercise and did not observe an effect of acute exercise on UCP3 mRNA (29). Pilegaard et al. (23) observed that UCP3 mRNA was upregulated 1-4 $\mathrm{h}$ after an acute bout of exercise. However, none of the studies mentioned above have addressed the possible effect of plasma FFA levels on UCP3 expression during exercise. Because high plasma FFA levels are associated with an upregulation of UCP3 mRNA and exercise is characterized by an increased level of plasma FFA, it is very well possible that the exercise-induced upregulation of UCP3 is not

The costs of publication of this article were defrayed in part by the payment of page charges. The article must therefore be hereby marked "advertisement" in accordance with 18 U.S.C. Section 1734 solely to indicate this fact. 
an exercise effect but an FFA-mediated effect. Therefore, the aim of the present study was to examine whether the upregulation of UCP3 mRNA expression after acute exercise is an effect of exercise per se or an effect of increased levels of plasma FFA. For this, UCP3 mRNA expression was measured immediately after as well as 1 and $4 \mathrm{~h}$ after a 2 -h exercise bout, which was performed one time without and one time with glucose ingestion. We have previously shown that glucose ingestion results in a marked reduction in FFA availability and fatty acid oxidation and a marked increase in plasma glucose levels and glucose oxidation (10). Because no data are available on the effect of exercise on UCP3 protein content, we also determined the latter in the present study.

\section{METHODS}

\section{Subjects}

Seven healthy, untrained male volunteers participated in this study. Subject characteristics are shown in Table 1. None of the subjects participated in endurance sports, but all were moderately active. The nature and risks of the experimental procedure were explained to the subjects, and all subjects gave their written informed consent. The study was approved by the Medical-Ethical Committee of Maastricht University.

\section{Experimental Design}

After an overnight fast, subjects came to the laboratory at 8:00 AM, and a percutaneous muscle biopsy was taken from the vastus lateralis muscle. After local anesthesia, a 5-mmdiameter side-cutting needle was passed through a $7-\mathrm{mm}$ skin incision. The muscle biopsy was frozen immediately in liquid nitrogen and stored at $-80^{\circ} \mathrm{C}$ until assayed. After this, a Teflon cannula was inserted in an antecubital vein for sampling of blood. Subjects rested on a bed, and a baseline blood sample was taken [baseline, time $(t)=-60 \mathrm{~min}$ ]. Immediately after the first blood sample was taken, subjects ingested $1.4 \mathrm{~g} / \mathrm{kg}$ body wt glucose (dissolved in water to a $20 \%$ solution and flavored with $1 \mathrm{ml}$ lemon juice). At $t=-10,30$, $60,90,180,240$, and $300 \mathrm{~min}$, subjects ingested $0.35 \mathrm{~g} / \mathrm{kg}$ body wt glucose (dissolved in water to a $10 \%$ solution and flavored with $1 \mathrm{ml}$ lemon juice).

After having rested for $1 \mathrm{~h}$, subjects started exercising at $50 \%$ of maximal power output $\left(\mathrm{W}_{\max } ; t=0 \mathrm{~min}\right)$. The exercise bout lasted for $2 \mathrm{~h}$, and during exercise blood samples were taken every $30 \mathrm{~min}$ (at $t=30,60,90$, and $120 \mathrm{~min}$ ). Immediately after cessation of the $2 \mathrm{~h}$ of exercise, a second muscle biopsy was taken $(t=120 \mathrm{~min})$. After the muscle biopsy was

Table 1. Subjects characteristics

\begin{tabular}{|c|c|}
\hline Subject & Mean \pm SE \\
\hline Age, yr & $22.7 \pm 0.6$ \\
\hline Height, m & $1.79 \pm 0.03$ \\
\hline Weight, kg & $76.4 \pm 3.7$ \\
\hline $\mathrm{BMI}, \mathrm{kg} / \mathrm{m}^{2}$ & $23.8 \pm 1.0$ \\
\hline $\mathrm{W}_{\max }, \mathrm{W}$ & $291 \pm 14$ \\
\hline $\mathrm{W}_{\max } / \mathrm{kg}, \mathrm{W} / \mathrm{kg}$ & $3.8 \pm 0.2$ \\
\hline$\dot{\mathrm{V}}_{2 \max }, \mathrm{ml} / \mathrm{min}$ & $3,852 \pm 211$ \\
\hline $\mathrm{V}_{2 \max }, \mathrm{ml} \cdot \min ^{-1} \cdot \mathrm{kg}^{-1}$ & $50.5 \pm 2.4$ \\
\hline
\end{tabular}

BMI, body mass index; $\dot{\mathrm{V}}_{2 \max }$, maximal $\mathrm{O}_{2}$ uptake; $\mathrm{W}_{\max }$, maximal power output.

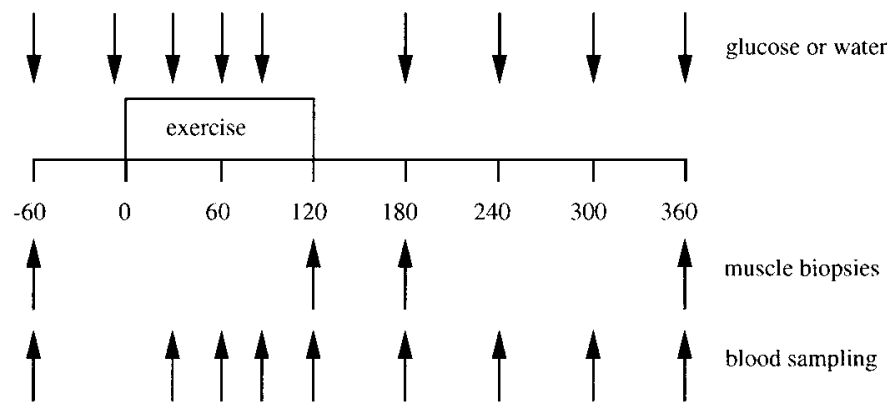

Fig. 1. Experimental design of the study. All subjects performed the protocol 2 times, 1 time in the fasted state and 1 time with glucose ingestion.

taken, subjects rested on a bed for $4 \mathrm{~h}$, and a third and fourth muscle biopsy was taken after $1(t=180 \mathrm{~min})$ and $4(t=360$ $\mathrm{min}$ ) h of rest. During this postexercise period, blood samples were taken every hour (at $t=180,240,300$, and $360 \mathrm{~min}$ ). The experimental design is depicted in Fig. 1.

Indirect calorimetry was performed continuously at rest and in the last $10 \mathrm{~min}$ of every half-hour during exercise. The entire protocol was repeated after at least $1 \mathrm{wk}$ but now with ingestion of equal amounts of water. Subjects started at random with either the water or the glucose trial.

\section{Procedures}

Maximal power output. Before the experiment (1 wk), each subject performed an incremental exercise test on an electromagnetically braked cycle ergometer (Lode Excalibur, Groningen, The Netherlands) to determine maximal oxygen consumption. Exercise was performed until voluntary exhaustion or until the subject could no longer maintain a pedaling rate of $\geq 60 \mathrm{rpm}$. Oxygen consumption $\left(\dot{\mathrm{V}}_{2}\right)$ and carbon dioxide production $\left(\dot{\mathrm{V}}_{2}\right)$ were measured using open circuit spirometry (Oxycon- $\beta$, Mijnhard, The Netherlands).

Muscle biopsy, UCP3 mRNA expression, and UCP3 protein content. Muscle biopsies were taken from the midthigh region from the vastus lateralis muscle according to the technique of Bergström et al. (3). Part of the biopsy was used for isolation of total RNA using the acid phenol method of Chomczynski and Sacchi (6), with an additional DNase digestion step with concomitant acid-phenol extraction and ethanol precipitation. UCP3L (390-nt-long) and UCP3S (436-nt-long) cDNA fragments were obtained by RT-PCR. The two competitor DNAs were obtained by a deletion of $40 \mathrm{bp}$ (20). For the assay, the RT reaction was performed from $0.2 \mu \mathrm{g}$ of skeletal muscle total RNA in the presence of a thermostable reverse transcription (Promega) by use of one of the specific antisense primers. The competitive PCR assays were performed as previously described $(19,20)$. To improve the quantification of the amplified products, fluorescent dye-labeled sense oligonucleotides were used. The PCR products were separated and analyzed on an ALFexpress DNA sequencer (Pharmacia) with the Fragment Manager Software. Total RNA preparations and RT-competitive PCR assays of the skeletal muscle samples from the same individual (before - after acute exercise) were performed simultaneously.

The remaining part of the muscle biopsies was homogenized in ice-cold Tris-EDTA buffer at $\mathrm{pH} 7.4$; thereafter, the homogenates were sonicated for $3 \times 5$ s. Subsequently, 2 vol of each skeletal muscle homogenate and 1 vol of SDS sample buffer were boiled for $4 \mathrm{~min}$ (17). Polyacrylamide gels (12\%) containing $0.1 \%$ SDS were loaded with equal amounts of protein of each sample, and electrophoresis was performed 
using a Mini-Protean 3 Electrophoresis Cell (Bio-Rad Laboratories, Hercules, CA), followed by Western blotting using a Mini Trans-Blot Electrophoretic Transfer Cell (Bio-Rad Laboratories). The separated polypeptides were transferred to a nitrocellulose membrane $(0.45 \mu \mathrm{m}$; Bio-Rad Laboratories) by blotting for $1 \mathrm{~h}$ at $100 \mathrm{~V}$ in a cold $\left(4^{\circ} \mathrm{C}\right)$ buffer containing 25 mM Tris, $192 \mathrm{mM}$ glycine, and 20\% methanol.

After protein transfer, nitrocellulose sheets were blocked with $5 \%$ nonfat dry milk in $0.05 \%$ Tween 20 -PBS; thereafter, antibody incubation was performed by gentle shaking overnight at room temperature at a dilution of 1:5,000 in 5\% nonfat dry milk in $0.05 \%$ Tween 20 -PBS. A rabbit polyclonal UCP3 antibody (code:1331, kindly provided from L. J. Slieker, Eli Lilly) prepared against a 20 -amino acid peptide (human sequence amino acids 147-166) that recognizes both the long and the short form of UCP3 and previously was shown not to recognize UCP2 was used (12). The antibody was affinity purified on a Sulfolink column (Pierce, Omnilabo International, Breda, The Netherlands) containing the peptide coupled through a $\mathrm{COOH}$-terminal Cys. Cross-reaction of the antibody with other proteins was checked for by examining the entire 5- to 94-kDa range for additional bands. The molecular mass of the band visualized by chemiluminescence was compared with reference values.

After antibody incubation, the blots were incubated for 60 min with horseradish peroxidase-conjugated swine anti-rabbit Ig (Dako) at a dilution of 1:10,000. The blots were washed for $2 \mathrm{~h}$ in $0.05 \%$ Tween 20-PBS and treated for 1 min with chemiluminescence substrate (Super Signal West Dura Extended Duration Substrate; Pierce). Finally, a clear blue X-ray film (CL-Xposure Film; Pierce) was exposed to the nitrocellulose sheets for $1 \mathrm{~min}$. The reaction product of each blot was analyzed by densitometry using Imagemaster (Pharmacia Biotech).

\section{Blood Analysis}

Blood was collected in tubes containing EDTA to prevent clotting and immediately centrifuged at 4,000 rpm for $10 \mathrm{~min}$ at $4^{\circ} \mathrm{C}$. Plasma was frozen in liquid nitrogen and stored at $-80^{\circ} \mathrm{C}$. Plasma substrates were determined using the hexokinase method (Roche, Basel, Switzerland) for glucose and the Wako NEFA C test kit (Wako Chemicals, Neuss, Germany) for FFA.

\section{Calculations}

From the recorded $\dot{\mathrm{V}}_{2}$ and $\dot{\mathrm{V}}_{\mathrm{CO}_{2}}$ (Oxycon- $\beta$ ), carbohydrate and fat oxidation rates and energy expenditure were calculated using the formulas of Péronnet and Masssicotte (22).

\section{Statistical Analysis}

Repeated-measures ANOVA was performed to examine differences in measured parameters between the glucose and fasted treatment at any time point. Two-way ANOVA was performed to examine interaction between time and treatments. For comparing overall differences between treatments, areas under the curve were calculated for $t=30$ to $t=$ 120 min during exercise and for $t=180$ to $t=360 \mathrm{~min}$ postexercise. Pearson correlation coefficients were calculated to determine the relationship between selected variables. All data are presented as means $\pm \mathrm{SE}$, and a $P$ value $<0.05$ was considered statistically significant.

\section{RESULTS}

\section{Energy Expenditure and Substrate Oxidation}

There were no significant differences in energy expenditure between the glucose treatment and the fasted state at baseline, during exercise, or postexercise (Table 2).

The respiratory quotient was significantly higher $(P<0.05)$ at every time point with the glucose treatment compared with the fasted state (Fig. 2). The area under the respiratory quotient vs. time curve was significantly higher with the glucose treatment compared with the fasted state during both exercise and postexercise $(P<0.05)$. Carbohydrate oxidation was significantly higher $(P<0.05)$ and fat oxidation was significantly lower $(P<0.05)$ at every time point with the glucose treatment compared with the fasted state (Table 2). During exercise, fat oxidation increased between $t=30$ and $t=120 \mathrm{~min}$ in both conditions $(P<0.001)$, but there was no time vs. treatment interaction. Carbohydrate oxidation decreased between $t=30$ and $t=$ 120 min with the glucose treatment $(P<0.05)$, whereas this decrease between $t=30$ and $t=120 \mathrm{~min}$ in the fasted state was almost significant (Table 2, $P=$ 0.06). In both conditions, carbohydrate and fat oxidation reached a steady state postexercise. The area under the carbohydrate oxidation vs. time curve was significantly higher with the glucose treatment compared with the fasted state during both exercise and postexercise $(P<0.05)$, whereas the area under the fat oxidation vs. time curve was lower with the glucose treatment compared with the fasted state $(P<0.05)$.

Table 2. Energy expenditure and fat and carbohydrate oxidation during and after exercise in the glucose and fasted treatment

\begin{tabular}{|c|c|c|c|c|c|c|c|}
\hline \multirow[b]{2}{*}{ Treatment } & \multirow[b]{2}{*}{$\underset{\text { min }}{\text { Time }}$} & \multicolumn{3}{|c|}{ Glucose } & \multicolumn{3}{|c|}{ Fasted } \\
\hline & & $\begin{array}{l}\mathrm{EE}, \mathrm{kJ} / \\
\min \end{array}$ & $\begin{array}{c}\text { Fat oxidation, } \\
\mathrm{mg} / \mathrm{min}\end{array}$ & $\begin{array}{l}\text { CHO oxidation, } \\
\text { mg/min }\end{array}$ & $\begin{array}{l}\mathrm{EE}, \mathrm{kJ} / \\
\min \end{array}$ & $\begin{array}{c}\text { Fat oxidation, } \\
\text { mg/min }\end{array}$ & $\begin{array}{c}\text { CHO oxidation, } \\
\mathrm{mg} / \mathrm{min}\end{array}$ \\
\hline \multirow[t]{5}{*}{ Exercise } & $0 *$ & $6.4 \pm 0.2$ & $88 \pm 24.2$ & $159 \pm 58 \dagger$ & $5.5 \pm 0.2$ & $87 \pm 9$ & $107 \pm 26$ \\
\hline & 30 & $45.0 \pm 2.0$ & $459 \pm 41 \dagger$ & $1,478 \pm 46 \dagger$ & $44.3 \pm 1.6$ & $617 \pm 41$ & $1,081 \pm 96$ \\
\hline & 60 & $45.6 \pm 2.2$ & $529 \pm 49 \dagger$ & $1,353 \pm 56 \dagger$ & $45.7 \pm 1.9$ & $682 \pm 38$ & $1,007 \pm 113$ \\
\hline & 90 & $46.7 \pm 2.5$ & $535 \pm 53 \dagger$ & $1,400 \pm 79 \dagger$ & $45.9 \pm 2.0$ & $740 \pm 46$ & $887 \pm 85$ \\
\hline & 120 & $46.5 \pm 2.7$ & $607 \pm 67 \dagger$ & $1,242 \pm 104 \dagger$ & $46.6 \pm 2.6$ & $732 \pm 55$ & $828 \pm 85$ \\
\hline \multirow[t]{4}{*}{ Postexercise } & 180 & $6.1 \pm 0.2$ & $45 \pm 9 \dagger$ & $241 \pm 13 \dagger$ & $5.9 \pm 0.2$ & $110 \pm 6$ & $79 \pm 15$ \\
\hline & 240 & $5.9 \pm 0.2$ & $54 \pm 8 \dagger$ & $207 \pm 13 \dagger$ & $6.0 \pm 0.2$ & $112 \pm 7$ & $79 \pm 8$ \\
\hline & 300 & $5.7 \pm 0.3$ & $52 \pm 8 \dagger$ & $203 \pm 21 \dagger$ & $5.8 \pm 0.2$ & $119 \pm 6$ & $52 \pm 9$ \\
\hline & 360 & $5.9 \pm 0.2$ & $48 \pm 4 \dagger$ & $221 \pm 16 \dagger$ & $5.7 \pm 0.2$ & $101 \pm 6$ & $92 \pm 7$ \\
\hline
\end{tabular}

Data are means \pm SE. EE, energy expenditure; CHO, carbohydrate. * Measured after glucose ingestion. $\dagger P<0.05$ compared with fasted treatment. 


\section{Blood Analysis}

Plasma FFA concentration (Fig. 3A) was significantly lower at every time point with the glucose treatment compared with the fasted state $(P<0.05)$. During exercise, plasma FFA concentration gradually increased in the fasted state $(P<0.0001)$, whereas in the glucose treatment an initial decline in plasma FFA levels was present $(319 \pm 19$ vs. $135 \pm 13$ at baseline and $t=30 \mathrm{~min}$, respectively, $P<0.05$ ). After the initial decline, plasma FFA levels also gradually increased with the glucose treatment $(P<0.001)$. There was a significant time vs. treatment interaction $(P<0.0001)$, indicating that plasma FFA levels increased significantly more in the fasted state compared with the glucose treatment during exercise. Postexercise plasma FFA levels were in a steady state in both conditions. The area under the plasma FFA level vs. time curve was significantly higher during both exercise and postexercise in the fasted state compared with the glucose treatment. Plasma glucose concentration (Fig. 3B) was significantly higher during exercise at $t=$ 90 and $120 \mathrm{~min}$ and $1(t=180 \mathrm{~min})$ and $4(t=360 \mathrm{~min})$ $\mathrm{h}$ postexercise $(P<0.05)$ with the glucose treatment compared with the fasted state. During exercise, plasma glucose concentration gradually decreased in the fasted state $(P<0.0001)$, whereas with the glucose treatment plasma glucose levels significantly increased between $t=30$ and $t=120 \mathrm{~min}(P<0.001)$. There was a significant time vs. treatment interaction $(P<0.0001)$. Postexercise plasma glucose levels were in a steady state in the fasted state, whereas with the glucose treatment plasma glucose was decreased $3 \mathrm{~h}$ postexercise (at $t=300 \mathrm{~min}$ ) compared with $1 \mathrm{~h}$ postexercise $(t=180 \mathrm{~min}, P=0.03)$. During both exercise and postexercise, the area under the plasma glucose levels vs. time curve tended to be significantly higher with the glucose treatment compared with the fasted state $(P=0.055)$.

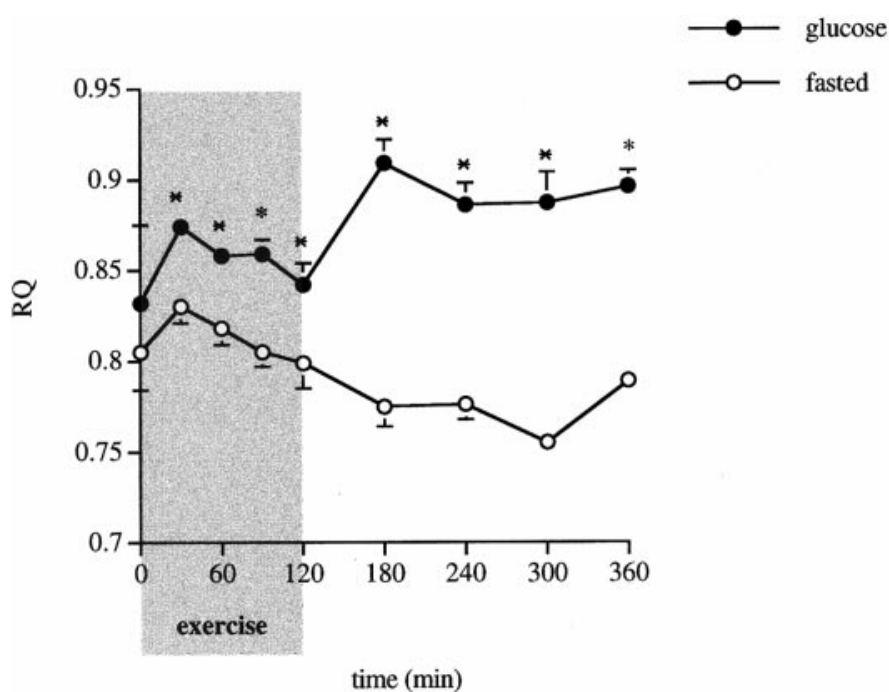

Fig. 2. Respiratory quotient (RQ) during and after $2 \mathrm{~h}$ of cycling at $50 \%$ maximal power output $\left(\mathrm{W}_{\max }\right)$, with and without glucose ingestion. ${ }^{*} P<0.05$ compared with fasting. Data are means $\pm \mathrm{SE}$.
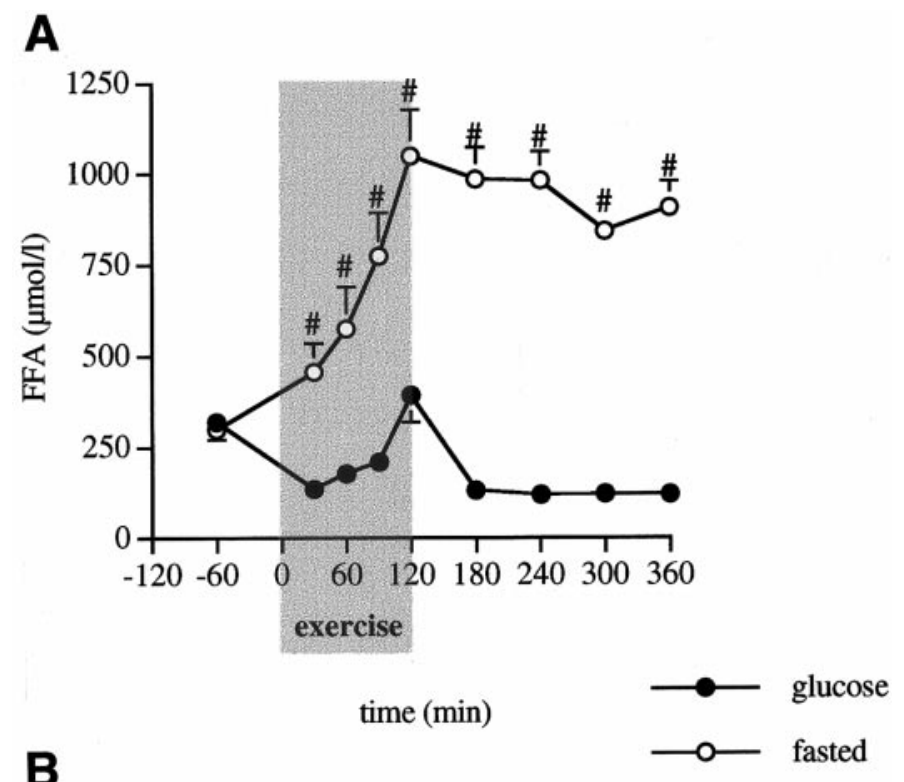

B

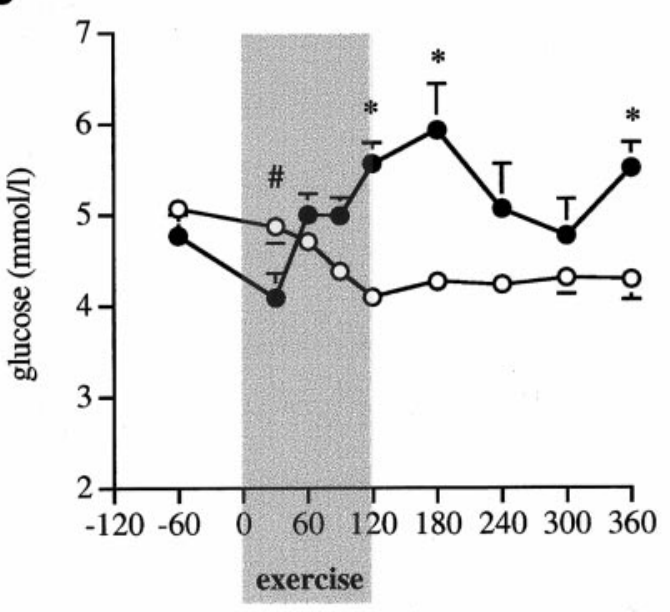

time $(\min )$

Fig. 3. Plasma levels of free fatty acid (FFA; $A$ ) and glucose $(B)$ during and after $2 \mathrm{~h}$ of cycling at $50 \% \mathrm{~W}_{\max }$, with and without glucose ingestion. ${ }^{*} P<0.05$ compared with fasting. $\# P<0.05$ compared with glucose. Data are means \pm SE.

\section{Effect of Acute Exercise on UCP3 $m R N A$ and UCP3 Protein Content}

At baseline, UCP3 mRNA expression and UCP3 protein content were not significantly different between the glucose treatment and fasted state. Acute exercise had no immediate effect on UCP3L mRNA expression. However, in the fasted state, UCP3L mRNA expression was increased significantly with, on average, $\sim 106 \%$ $4 \mathrm{~h}$ postexercise $(t=360 \mathrm{~min})$ compared with baseline, immediately after exercise $(t=120 \mathrm{~min})$, and $1 \mathrm{~h}$ postexercise $(t=180 \mathrm{~min} ; P<0.05$, Fig. 4$)$. With the glucose treatment, no differences in UCP3L mRNA expression were observed $(P=0.43)$. UCP3L mRNA expression tended to be higher in the fasted state compared with glucose treatment $4 \mathrm{~h}$ postexercise (at $t=360 \mathrm{~min}, P=0.07$ ). No differences in UCP3S mRNA expression between conditions and/or time 


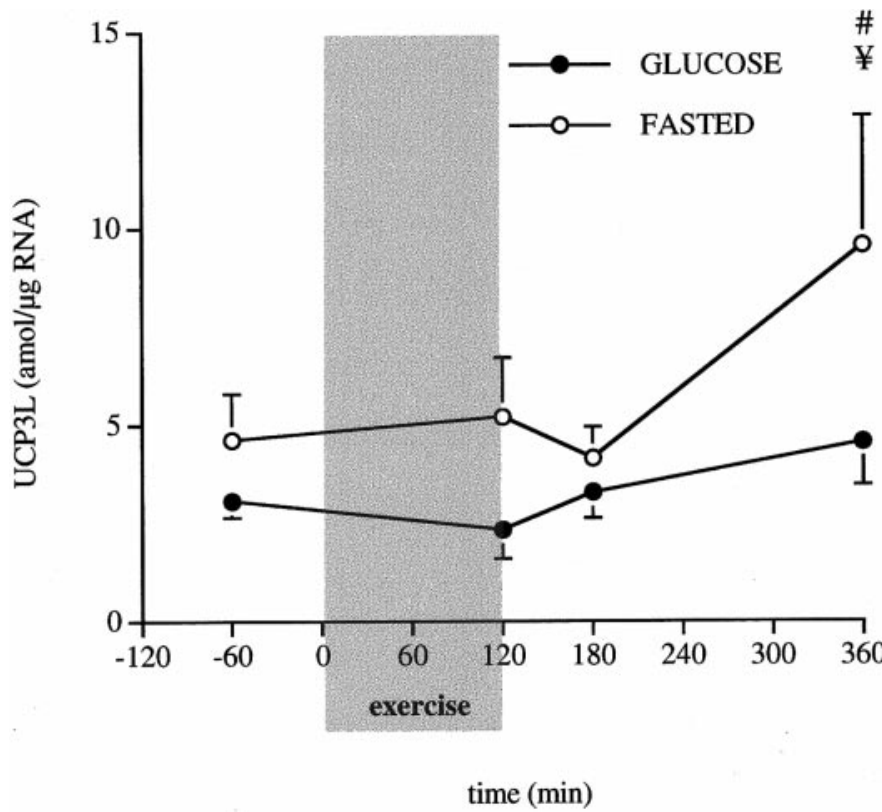

Fig. 4. Skeletal muscle mRNA expression of the long isoform of uncoupling protein (UCP)3 (UCP3L) during and after $2 \mathrm{~h}$ of cycling at $50 \% \mathrm{~W}_{\max }$, with and without glucose ingestion. $\# P=0.07 \mathrm{com}-$ pared with glucose. $¥ P<0.05$ compared with $t=-60,120$, and 180 min in fasted treatment only. Data are means $\pm \mathrm{SE}$.

points were observed (Table 3). UCP3 protein content did not change significantly during or after exercise in any of the conditions and was not significantly different between the glucose treatment and fasted state at any time point measured (Table 3 ).

\section{DISCUSSION}

Acute exercise has been shown to result in an upregulation of UCP3 mRNA expression $(9,23,32,36)$. Acute exercise also results in an increase in plasma FFA levels, and it has been shown that FFA upregulate UCP3 mRNA expression $(15,35)$. In the present study, we examined the effect of $2 \mathrm{~h}$ of moderate-intensity exercise on UCP3 mRNA in two different situations (with high and low plasma FFA levels). The data show clearly that this exercise regime resulted in an upregulation of UCP3L mRNA, but only when plasma FFA were elevated for several hours. Acute exercise without elevation of plasma FFA levels, but with high plasma glucose levels and glucose oxidation, does not lead to significant changes in UCP3L mRNA expression in muscle. The short isoform of UCP3, which lacks the last coding exon, was not upregulated in either treatment. UCP3S mRNA likely results in a truncated protein, lacking the sixth transmembrane domain (4) and possibly leading to altered uncoupling activity. However, the precise function of the two isoforms is presently unknown. Furthermore, the upregulation of UCP3L mRNA was not accompanied by changes in UCP3 protein content over this 4-h postexercise period, suggesting that the translation of UCP3 mRNA into protein requires more than these $4 \mathrm{~h}$. This is not surprising when it is considered that the half-life of
UCP1 protein, a mitochondrial protein with high homology to UCP3, is $\sim 5$ days, which would indicate that several days are needed for changes in mRNA to become evident as changes in protein (21). Taken together, our results show that the effect of a 2 -h exercise bout of moderate intensity on UCP3L mRNA is not an exercise effect per se but rather a fat metabolismmediated effect.

The function of human UCP3 is presently unknown. Because UCP3 is expressed specifically in skeletal muscle in humans (4) and because skeletal muscle is known to be an important thermogenic organ (1), UCP3 has been considered to be involved in human energy metabolism. Acute exercise is characterized by marked increases in energy expenditure, both during and after the exercise bout. Therefore, the effect of acute exercise on UCP3 expression has been investigated previously. Zhou et al. (36) showed that UCP3 mRNA expression was upregulated sevenfold after 30 min of treadmill running in rats. Similarly, Cortright et al. (9) observed that, after $1 \mathrm{~h}$ of treadmill running, UCP3 mRNA expression was elevated 63 and $252 \%$ in red and white gastrocnemius muscle, respectively. Tsuboyama-Kasaoka et al. (32) showed that UCP3 mRNA levels in rats were upregulated $3 \mathrm{~h}$ after $1 \mathrm{~h}$ of swimming but returned to baseline $22 \mathrm{~h}$ postexercise. In humans, Pilegaard et al. (23) showed that UCP3 mRNA was upregulated $4 \mathrm{~h}$ after acute exercise. These data are consistent with a role for UCP3 in the regulation of energy metabolism. However, there are also data that seem to be incompatible with the concept of energy dissipation. For example, UCP3 expression in skeletal muscle is increased during fasting $(19,24)$, an energy turnover-attenuating condition. Because UCP3 also increases upon high-fat feeding (35) and fasting results in elevated levels of plasma FFA levels, it has been suggested that changes in fatty acid metabolism are responsible for the increased UCP3 expression during fasting and high-fat feeding. According to some theories, the uncoupling function of UCP3 involves the outward transport of fatty acid anions across the inner mitochondrial membrane (13). This also suggests that it is not necessarily the amount of plasma FFA that determines the expression of UCP3 but rather the delivery of fatty acids to the mitochondria or the concentration of fatty acids inside the mitochondria. In-

Table 3. UCP3S mRNA expression and UCP3 protein content during and after exercise in the glucose and fasted treatment

\begin{tabular}{|c|c|c|c|c|}
\hline \multirow{2}{*}{$\begin{array}{l}\text { Time, } \\
\text { min }\end{array}$} & \multicolumn{2}{|c|}{$\begin{array}{l}\text { UCP3S mRNA, } \\
\mathrm{amol} / \mu \mathrm{g} \text { RNA }\end{array}$} & \multicolumn{2}{|c|}{ UCP3 Protein, AU } \\
\hline & Glucose & Fasted & Glucose & Fasted \\
\hline-60 & $2.8 \pm 0.4$ & $5.8 \pm 1.9$ & $1.2 \pm 0.3$ & $1.2 \pm 0.2$ \\
\hline 120 & $2.2 \pm 0.7$ & $4.7 \pm 1.9$ & $1.1 \pm 0.2$ & $0.9 \pm 0.2$ \\
\hline 180 & $3.4 \pm 0.7$ & $4.4 \pm 1.7$ & $0.9 \pm 0.1$ & $1.2 \pm 0.2$ \\
\hline 360 & $3.8 \pm 1.1$ & $5.5 \pm 2.0$ & $1.0 \pm 0.2$ & $0.9 \pm 0.1$ \\
\hline
\end{tabular}

Data are means \pm SE. UCP, uncoupling protein; UCP3S, short isoform of UCP3; AU, arbitrary units. 
hibiting fatty acid oxidation by administration of etomoxir, a blocker of carnitine palmitoyltransferase I (the rate-limiting enzyme for uptake of fatty acids by the mitochondria), results in a decrease in UCP3 mRNA expression, even though plasma FFA levels are high (25). This suggests that UCP3 expression could be related to fatty acid oxidation. Further evidence for the latter comes from our recent finding (27) that UCP3 mRNA expression was upregulated after consumption of a high-fat diet for $4 \mathrm{wk}$, which is known to result in an increase in fatty acid oxidation, whereas plasma FFA levels are known to be unaltered after long-term high-fat diets $(26,27)$.

Because acute exercise not only results in an increase in energy expenditure but also increases plasma FFA levels and fat oxidation, we examined in the present study whether the increase in UCP3 mRNA after acute exercise could be more directly related to changes in fat metabolism instead of to changes in energy metabolism. We found that the effect of $2 \mathrm{~h}$ of moderate-intensity exercise on UCP3 mRNA expression is not a direct effect of exercise per se but rather an effect of sustained elevated plasma FFA levels and/or increased fatty acid oxidation. Because there was no difference in energy expenditure between the fasted and glucose treatments, the results show that the upregulation of UCP3L after exercise does not seem to be related to exercise-induced changes in energy metabolism. This might indicate, but does not necessarily prove, that the primary function of skeletal muscle UCP3 during exercise is not related to the regulation of energy metabolism. Alternatively, UCP3 might play a role in fatty acid metabolism. We recently postulated a hypothesis concerning an alternative function for UCP3 (28). In short, small amounts of neutral fatty acids are believed to be able to cross membranes by flip-flop (11), and neutral fatty acids might thus reach the mitochondrial matrix. The entry of fatty acids into the mitochondrial matrix via flip-flop might be particularly true in situations when fatty acid flux in the cells exceeds the capacity to metabolize these fatty acids and thus fatty acid concentrations inside the cells would start to increase, as can be expected to be the case in the present study. Because the fatty acids that enter the mitochondrial matrix will be deprotonated (because of the proton gradient) and because fatty acid anions are not able to flip-flop (11), we hypothesize that UCP3 might be involved in the outward translocation of fatty acid anions across the inner mitochondrial membrane. Note that, as a result, UCP3 would lower the proton gradient across the inner mitochondrial membrane, explaining the previously observed relation between UCP3 and energy metabolism $(5,7,31,34)$. The results from the present study are compatible with this hypothesis, but further studies are necessary to examine this putative function of UCP3.

Another postulated function of UCP3 is defense against reactive oxygen species (ROS; see Ref. 33). It has been shown that an increase in mitochondrial membrane potential results in the formation of ROS
(16). Furthermore, ROS formation is increased during and after exercise (8). Because UCP3 decreases mitochondrial membrane potential, high levels of UCP3 during and after exercise could be helpful in the prevention of the formation of ROS. Therefore, an upregulation of UCP3 after acute exercise would be consistent with a role for UCP3 in the defense against oxidative stress. However, our finding that UCP3 is not upregulated after acute exercise in the glucose-treated condition would implicate that either UCP3 does not play a role in the defense of ROS formation or that the exercise-induced formation of ROS is lower in the glucosefed state. Indeed, high intracellular levels of fatty acids result in increased ROS formation, and it might thus be that UCP3 specifically plays a role in preventing fatty acid-induced ROS formation (18). As stated above, we hypothesize that UCP3 is upregulated in situations when fatty acid flux into the mitochondria exceeds the capacity to metabolize these fatty acids and would thereby both reduce ROS formation and, by translocating the fatty acid anions across the mitochondrial membrane out of the matrix, prevent these fatty acids from lipid peroxidation.

In conclusion, we found that $2 \mathrm{~h}$ of exercise at moderate intensity had no direct effect on UCP3L mRNA expression. Abolishing the commonly observed increase in plasma FFA levels and/or fatty acid oxidation during and after exercise also prevented the upregulation of UCP3L after exercise. These results suggest that UCP3 is involved in fatty acid metabolism and is upregulated in situations when fatty acid flux into the mitochondria exceeds the capacity to metabolize these fatty acids. A possible function for UCP3 might be to reduce ROS formation and, by translocating the fatty acid anions across the mitochondrial membrane out of the matrix, prevent these fatty acids from lipid peroxidation. However, further studies are needed to test this hypothesis.

We thank Lawrence J Slieker from Eli Lilly for providing us with the uncoupling protein 3 antibody.

This work was supported by a grant from the Human Nutrition Institute of the International Life Sciences Institute Research Foundation (ILSI RF). The opinions expressed herein are those of the author(s) and do not necessarily represent the views of the ILSI RF. P. Schrauwen was supported by a grant from the Netherlands Organization for Scientific Research. A. Russell was supported by grants from the Office Féderal du Sport Macolin, Fonds Eugène Rapin, and the Fondation du Centenaire de la Société Suisse d'Assurances générales sur la vie humaine pour la santé publique et les recherches médicales.

\section{REFERENCES}

1. Astrup A, Bülow J, Madsen J, and Christensen NJ. Contribution of BAT and skeletal muscle to thermogenesis induced by ephedrine in man. Am J Physiol Endocrinol Metab 248: E507E515, 1985.

2. Bao S, Kennedy A, Wojciechowski B, Wallace P, Ganaway E, and Garvey WT. Expression of mRNAs encoding uncoupling proteins in human skeletal muscle: effects of obesity and diabetes. Diabetes 47: 1935-1940, 1998.

3. Bergström J, Hermansen L, Hultman E, and Saltin B. Diet, muscle glycogen and physical performance. Acta Physiol Scand 71: $140-150,1967$. 
4. Boss O, Samec S, Paoloni-Giacobino A, Rossier C, Dulloo A, Seydoux J, Muzzin P, and Giacobino JP. Uncoupling protein-3: a new member of the mitochondrial carrier family with tissue-specific expression. FEBS Lett 408: 39-42, 1997.

5. Bouchard C, Pérusse L, Chagnon YC, Warden G, and Ricquier D. Linkage between markers in the vicinity of the uncoupling protein 2 gene and resting metabolic rate in humans. Hum Mol Genet 6: 1887-1889, 1997.

6. Chomczynski P and Sacchi N. Single-step method of RNA isolation by acid guanidinium thiocyanate-phenol-chloroform extraction. Anal Biochem 162: 156-159, 1987.

7. Clapham JC, Arch JR, Chapman H, Haynes A, Lister C, Moore GB, Piercy V, Carter SA, Lehner I, Smith SA, Beeley LJ, Godden RJ, Herrity N, Skehel M, Changani KK, Hockings PD, Reid DG, Squires SM, Hatcher J, Trail B, Latcham J, Rastan S, Harper AJ, Cadenas S, Buckingham JA, Brand MD, and Abuin A. Mice overexpressing human uncoupling protein-3 in skeletal muscle are hyperphagic and lean. Nature 406: 415-418, 2000.

8. Clarkson PM and Thompson HS. Antioxidants: what role do they play in physical activity and health? Am J Clin Nutr 72 : 637S-646S, 2000.

9. Cortright RN, Zheng D, Jones JP, Fluckey JD, DiCarlo SE, Grujic D, Lowell BB, and Dohm GL. Regulation of skeletal muscle UCP-2 and UCP-3 gene expression by exercise and denervation. Am J Physiol Endocrinol Metab 276: E217-E221, 1999.

10. Coyle EF, Jeukendrup AE, Wagenmakers AJM, and Saris WHM. Fatty acid oxidation is directly regulated by carbohydrate metabolism during exercise. Am J Physiol Endocrinol Metab 273: E268-E275, 1997.

11. Hamilton JA and Kamp F. How are free fatty acids transported in membranes? Is it by proteins or by free diffusion through the lipids? Diabetes 48: 2255-2269, 1999.

12. Hesselink MKC, Keizer HA, Borghouts LB, Schaart G, Kornips CFP, Slieker LJ, Sloop KW, Saris WHM, and Schrauwen P. Protein expression of UCP3 differs between human type 1, type $2 \mathrm{a}$ and type 2 b fibers. FASEB $J 15$ : 10.1096/ fj.00-0517fje, 2001.

13. Jezek $P$, Engstová $H$, Zácková $M$, Vercesi AE, Costa ADT, Arruda P, and Garlid KD. Fatty acid cycling mechanism and mitochondrial uncoupling proteins. Biochim Biophys Acta 1365: 319-327, 1998.

14. Keys A, Brozek J, Henschel A, Mickelsen O, and Taylor HL. The Biology of Human Starvation. Minneapolis, MN: Univ of Minesota, 1950.

15. Khalfallah Y, Fages S, Laville $M$, Langin $D$, and Vidal $H$. Regulation of uncoupling protein-2 and uncoupling protein-3 mRNA expression during lipid infusion in human skeletal muscle and subcutaneous adipose tissue. Diabetes 49: 25-31, 2000.

16. Korshunov SS, Skulachev VP, and Starkov AA. High protonic potential actuates a mechanism of production of reactive oxygen species in mitochondria. FEBS Lett 416: 15-18, 1997.

17. Laemmli UK. Cleavage of structural proteins during the assembly of the head of bacteriophage T4. Nature 227: 680-685, 1970.

18. Maziere C, Conte MA, Degonville J, Ali D, and Maziere JC. Cellular enrichment with polyunsaturated fatty acids induces an oxidative stress and activates the transcription factors AP1 and NFkappaB. Biochem Biophys Res Commun 265: 116-122, 1999.

19. Millet L, Vidal H, Andreelli F, Larrouy D, Riou JP, Ricquier D, Laville $\mathbf{M}$, and Langin D. Increased uncoupling protein-2 and -3 mRNA expression during fasting in obese and lean humans. J Clin Invest 100: 2665-2670, 1997.

20. Millet L, Vidal H, Larrouy D, Andreelli F, Laville M, and Langin D. mRNA expression of the long and short forms of uncoupling protein-3 in obese and lean humans. Diabetologia 41: 829-832, 1998.

21. Nedergaard J, Golozoubova V, Matthias A, Asadi A, Jacobsson A, and Cannon B. UCP1: the only protein able to mediate adaptive non-shivering thermogenesis and metabolic inefficiency. Biochim Biophys Acta 1504: 82-106, 2001.

22. Péronnet $\mathbf{F}$ and Masssicotte $\mathbf{D}$. Table of nonprotein respiratory quotient: an update. Can J Sport Sci 16: 23-29, 1991.

23. Pilegaard H, Ordway GA, Saltin B, and Neufer PD. Transcriptional regulation of gene expression in human skeletal muscle during recovery from exercise. Am J Physiol Endocrinol Metab 279: E806-E814, 2000.

24. Samec S, Seydoux J, and Dulloo AG. Post-starvation gene expression of skeletal muscle uncoupling protein 2 and uncoupling protein 3 in response to dietary fat levels and fatty acid composition. A link with insulin resistance. Diabetes 48: 436441, 1999.

25. Samec S, Seydoux J, and Dulloo AG. Skeletal muscle UCP3 and UCP2 gene expression in response to inhibition of free fatty acid flux through mitochondrial beta-oxidation. Pflügers Arch 438: 452-457, 1999.

26. Schrauwen P, Hoppeler H, Billeter R, Bakker A, and Pendergast D. Fiber type dependent upregulation of human skeletal muscle UCP2 and UCP3 mRNA expression by high-fat diet. Int J Obes Relat Metab Disord 25: 449-456, 2001.

27. Schrauwen P, van Marken Lichtenbelt WD, Saris WHM, and Westerterp KR. Changes in fat oxidation in response to a high-fat diet. Am J Clin Nutr 66: 276-282, 1997.

28. Schrauwen P, Saris WHM, and Hesselink MKC. An alternative function for human uncoupling protein 3: protection of mitochondria against accumulation of non-esterified fatty acids inside the mitochondrial matrix. FASEB $J$ In press.

29. Schrauwen P, Troost FJ, Xia J, Ravussin E, and Saris WHM. Skeletal muscle UCP2 and UCP3 expression in trained and untrained male subjects. Int J Obes 23: 966-972, 1999.

30. Schrauwen $\mathbf{P}$, Walder $\mathbf{K}$, and Ravussin E. Human uncoupling proteins and obesity. Obesity Res 7: 97-105, 1999.

31. Schrauwen P, Xia J, Bogardus C, Pratley R, and Ravussin E. Skeletal muscle UCP3 expression is a determinant of energy expenditure in Pima Indians. Diabetes 48: 146-149, 1999.

32. Tsuboyama-Kasaoka N, Tsunoda N, Maruyama K, Takahashi M, Kim H, Ikemoto S, and Ezaki O. Up-regulation of uncoupling protein 3 (UCP3) mRNA by exercise training and down-regulation of UCP3 by denervation in skeletal muscles. Biochem Biophys Res Commun 247: 498-503, 1998.

33. Vidal-Puig AJ, Grujic D, Zhang CY, Hagen T, Boss O, Ido Y, Szczepanik A, Wade J, Mootha V, Cortright R, Muoio DM, and Lowell BB. Energy metabolism in uncoupling protein 3 gene knockout mice. J Biol Chem 275: 16258-16266, 2000.

34. Walder K, Norman RA, Hanson RL, Schrauwen P, Neverova M, Jenkinson CP, Easlick J, Warden CH, Pecqueur C, Raimbault S, Riquier D, Silver MHK, Shuldiner AR, Solanes G, Lowell BB, Chung WK, Leibel RL, Pratley R, and Ravussin E. Association between uncoupling protein polymorphisms (UCP2-UCP3) and energy metabolism/obesity in Pima Indians. Hum Mol Genet 7: 1431-1435, 1998.

35. Weigle DS, Selfridge LE, Schwartz MW, Seeley RJ, Cummings DE, Havel PJ, Kuijper JL, and BertrandelRio $H$. Elevated free fatty acids induce uncoupling protein 3 expression in muscle. A potential explanation for the effect of fasting. Diabetes 47: 298-302, 1998.

36. Zhou M, Lin BZ, Coughlin S, Vallega G, and Pilch PF. UCP-3 expression in skeletal muscle: effects of exercise, hypoxia, and AMP-activated protein kinase. Am J Physiol Endocrinol Metab 279: E622-E629, 2000. 